\title{
Factory Laborer Dies When a Car Driven by Coworker Crashes into Him in Parking Lot
}

\author{
Incident Number: 12KY037
}

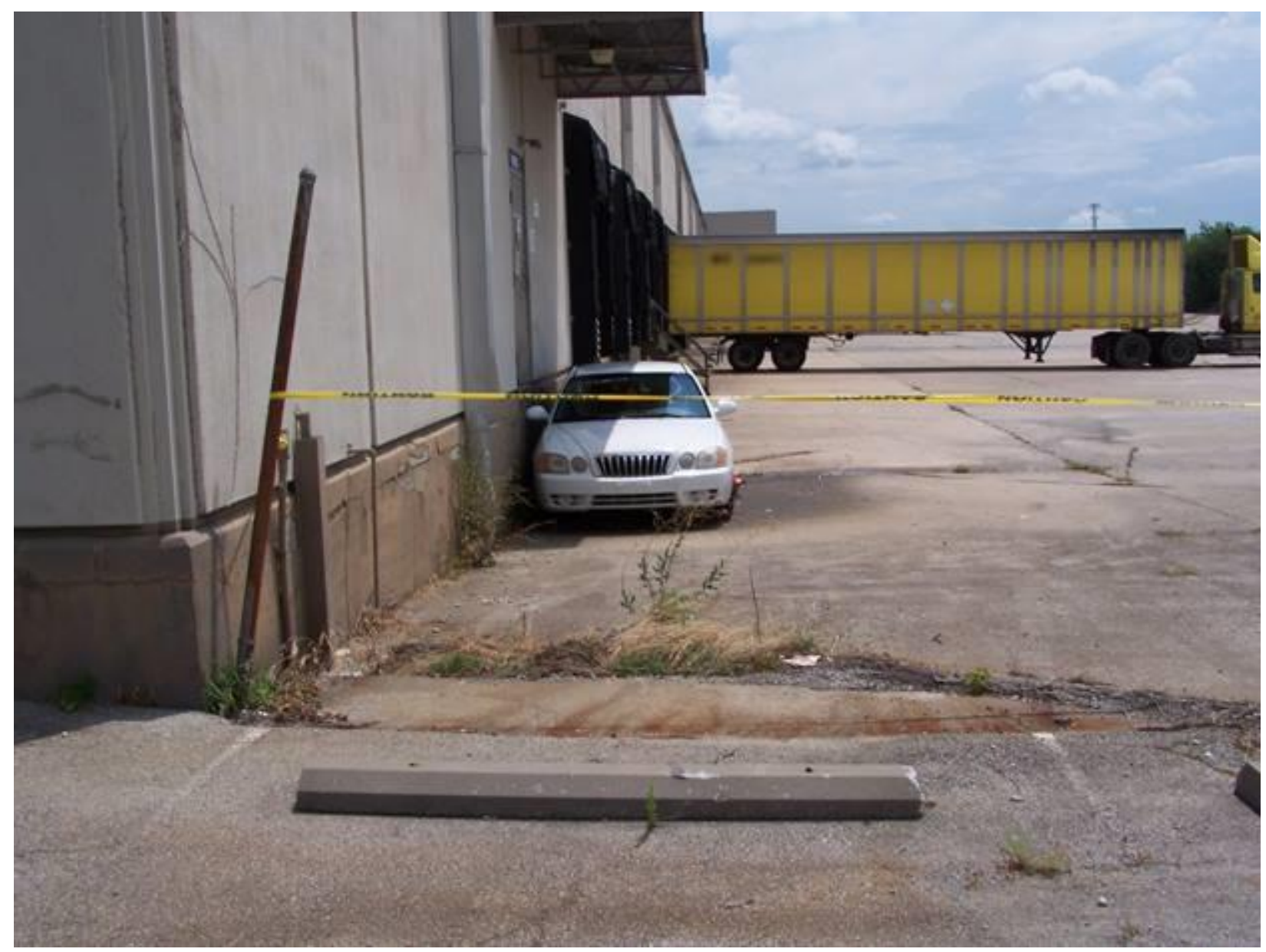

The car in the area where the crash occurred. Photograph property of KY FACE program.

Kentucky Fatality Assessment and Control Evaluation Program Kentucky Injury Prevention and Research Center 333 Waller Avenue

Suite 242

Lexington, Kentucky 40504

Phone: 859-323-2981

Fax: 859-257-3909

www.kiprc.uky.edu

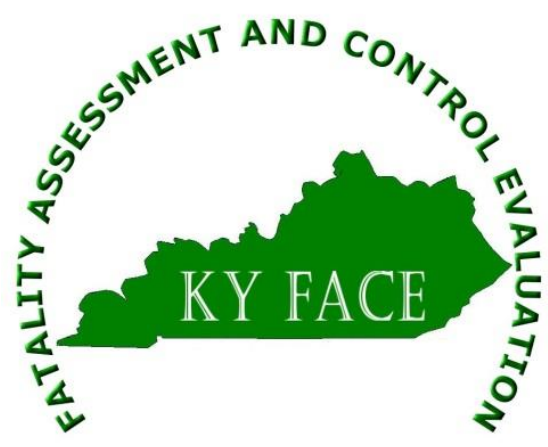




\title{
Kentucky Fatality Assessment and Control Evaluation (FACE) Program Incident Number: 12KY037 Release Date: June 30, 2013 Subject: Factory Laborer Dies When a Car Driven by Coworker Crashes into Him in the Parking Lot
}

\begin{abstract}
Summary
On a summer day, a 29-year-old male manufacturing laborer was outside under a small metal stairway in the loading dock area of the manufacturing plant during his lunch break. Another employee entered her car in the employee parking lot to leave on her lunch break. Her car unexpectedly malfunctioned when in reverse, sped backward, and crashed into the stairway under which the worker was taking a break. The collision pushed the metal stairway along the wall of the factory, crushing the worker between the building and the passenger side of the car. Emergency medical services arrived and transported the worker to the nearest hospital. From there, the worker was flown to the nearest trauma hospital, where he died shortly after arriving.
\end{abstract}

To prevent future occurrences of similar incidents, the following recommendations have been made:

Recommendation No. 1: Employers should establish policies requiring employees to use the safe break areas that are provided.

Recommendation No. 2: Outdoor break areas, if provided, should be in areas that are separated from vehicular traffic.

\section{Background}

A male laborer, an immigrant from Guatemala, worked for a manufacturing company that distributed contact paper and construction paper. There were approximately 40 employees working at this facility. The plant where this laborer worked was one location of the larger company, whose headquarters was based in a distant state. Safety training had been provided to the laborer at employee orientation as well as information about the location of break areas. The laborer had also been employed as a landscape worker for many years. It is unknown how long he had worked at the plant or how long he had been living in the United States.

On the day of the incident the temperature ranged from 71 to 84 degrees Fahrenheit and there was no precipitation.

\section{Investigation}

The Kentucky Fatality Assessment and Control Evaluation Program was notified of an occupational fatality involving a factory laborer who was struck by a coworker's car. Interviewed for this report were the responding police officer and the on-site factory manager. A site visit was made three days after the incident and photographs were taken. 
On a sunny summer day shortly before noon, a 29-year-old male factory laborer (Laborer 1) left his workstation to take a lunch break underneath a small metal stairway in the loading dock area. Coworkers revealed that it was the habit of Laborer 1 to take a nap or make cell phone calls outside under this metal stairway during his lunch break each day. The part of the loading dock area where the laborer was taking his break was separated from the employee parking lot by a chain link fence. The distance from the fence to the metal stairway was approximately $30-35$ feet. On the day of the incident, another laborer (Laborer 2) entered her car with a friend to go out for lunch. She started her car, engaged it in reverse, and proceeded to back out of her parking space which was directly in line with Laborer 1 sitting underneath the stairway (See Diagram - Attachment 2).

Laborer 2 reported that a vehicle malfunction occurred as she backed up, causing the accelerator to become stuck. The car suddenly sped backward, over a concrete wheel stop, through a chainlink fence, scraping the passenger side of the car against the side of the building, and crashed into the metal stairway under which Laborer 1 was sitting. The car continued traveling backward alongside the building and the force of the car moved the metal stairway approximately 15 feet. Laborer 1 had just arrived underneath the metal stairway, according to coworkers, and was crushed between the building and the passenger side of the car.

Coworkers heard noise outside the building and rushed to the loading dock area where they found the metal stairway on the back of the car and Laborer 1 trapped between the car and the building. Emergency medical services were immediately contacted and dispatched to the factory. A forklift was used to move the metal stairway from the back of the car and give emergency workers access to Laborer 1. Laborer 1 was removed and transported to the nearest hospital. From there he was flown by helicopter to the nearest trauma hospital, where he died shortly after his arrival, about three hours after the crash.

\section{Cause of Death}

The cause of death was multiple blunt force injuries sustained in a motor vehicle versus pedestrian collision.

\section{Recommendations and Discussions}

\section{Recommendation No. 1: Employers should establish policies requiring employees to use the safe break areas that are provided.}

Co-workers of Laborer 1 revealed that it was his habit to take a break outside underneath a small metal stairway in the loading dock area during his lunch break each day. This location gave him privacy and was relatively quiet, but this area was near the loading docks and was surrounded by concrete, metal and vehicles in motion. Employers should provide safe and protected areas for employees to take breaks and require that employees use the designated break areas when on the property for breaks. Employees should refrain from taking breaks in areas that are inherently unsafe. At the factory where the incident occurred, there were two designated break areas, one indoor and one outdoor under a tree next to the employee parking lot. 


\section{Recommendation No. 2: Outdoor break areas, if provided, should be in areas that are separated from vehicular traffic.}

At the time of the incident described in this report, the outside break area at this facility was at a picnic table under a tree on one side of the employee parking lot. The break area was separated from the parking lot by concrete wheel stops and grass. Based on this fatality investigation, the factory management moved the outdoor break area to a safer location, away from moving vehicles. The outdoor break area is now between two manufacturing buildings, barricaded from vehicles.

As an alternative to moving the break area, additional exterior barriers could be installed to protect employees. ASTM International, the General Services Administration, and other federal agencies have criteria and specifications for the use of various protective devices. Relevant documents published by these groups can be useful in assessing potentially vulnerable locations and developing site-specific protections.

\section{Keywords}

Break Areas

Parking Lots

\section{References}

http://www.dir.ca.gov/dlse/faq_restperiods.htm http://www.sandiego.gov/park-and-recreation/pdf/parkdesign/bpmasterplan.pdf http://www.desman.com/?gclid=CITos5_dq7ICFaReTAoddz4AgQ http://www.ncpc.gov/DocumentDepot/Publications/SecurityPlans/DesignTestPerimSecurity.pdf

\section{Acknowledgements}

The Kentucky FACE program would like to thank the police department and the factory management for their assistance with this report.

The Kentucky Fatality Assessment \& Control Evaluation Program (FACE) is funded by grant 2U60OH008483-09 from the Centers for Disease Control and the National Institute for Occupational Safety and Health. The purpose of FACE is to aid in the research and prevention of occupational fatalities by evaluating events leading to, during, and after a work related fatality. Recommendations are made to help employers and employees have a safer work environment. For more information about FACE and KIPRC, please visit our website at: www.kiprc.uky.edu 
Attachment 1

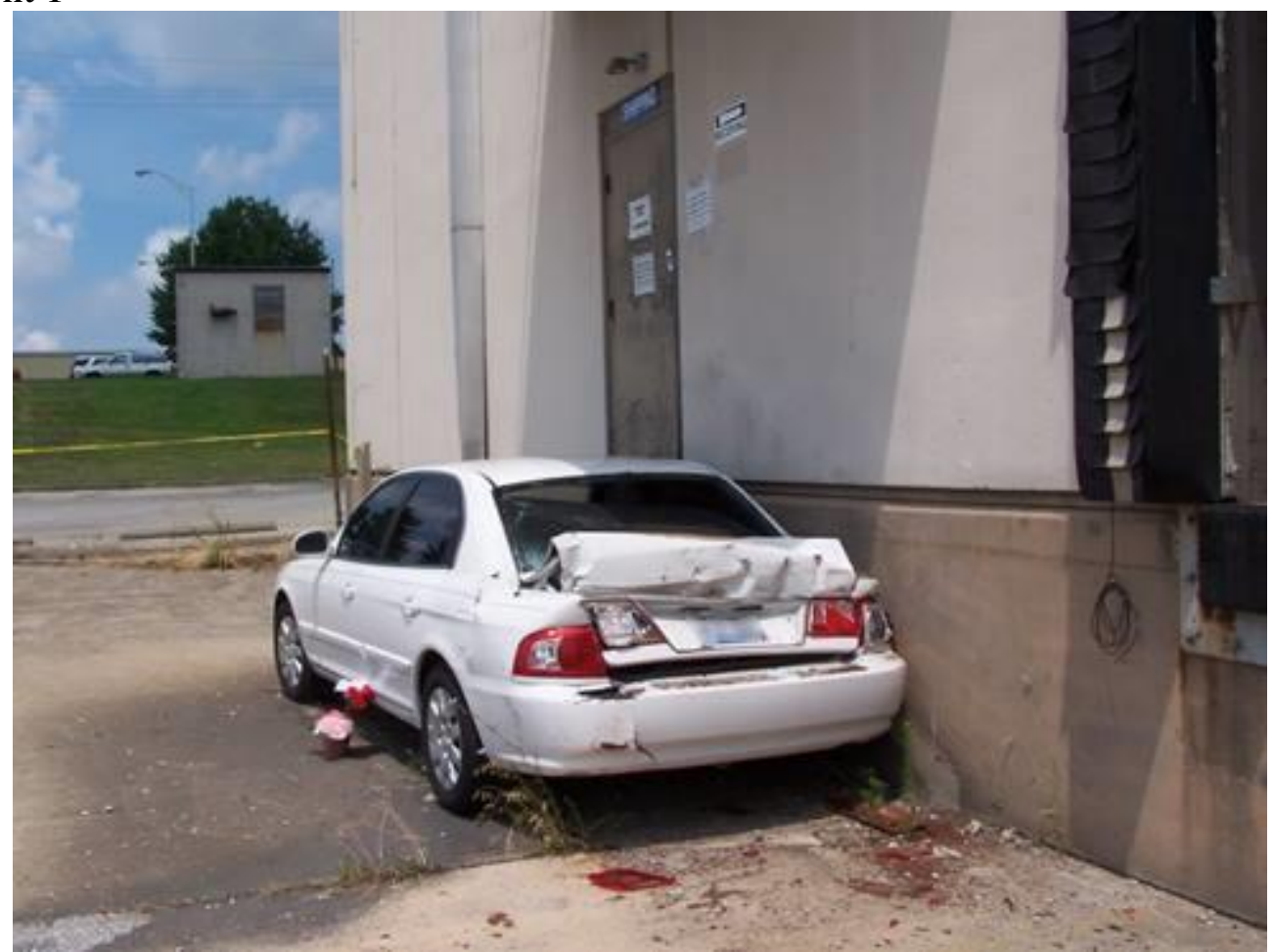

The car crashed into the metal stairway, pushing it backward from underneath the door in the picture. Laborer 1 had been under the stairway. The stairway had been removed when this photo was taken. Photograph property of KY FACE

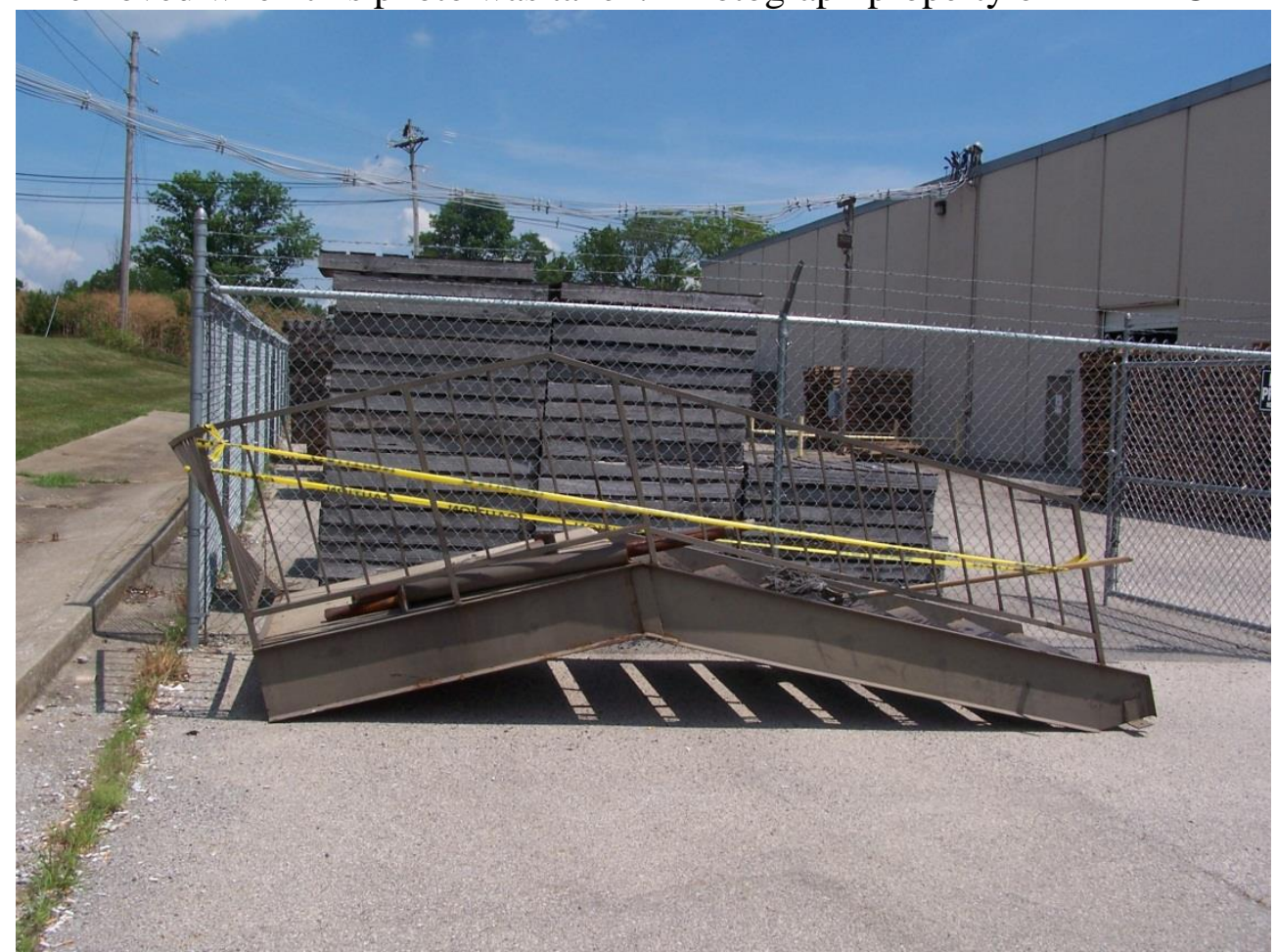

The metal stairway which had been attached to the building under the door.

Laborer 1 was reported to take breaks under this structure. Photograph property of KY FACE 
Storage area surrounded by chain link fence

Tree with picnic table/ original outdoor break area
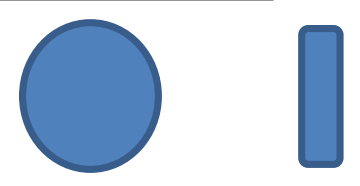

\section{Main Entrance} Building 1
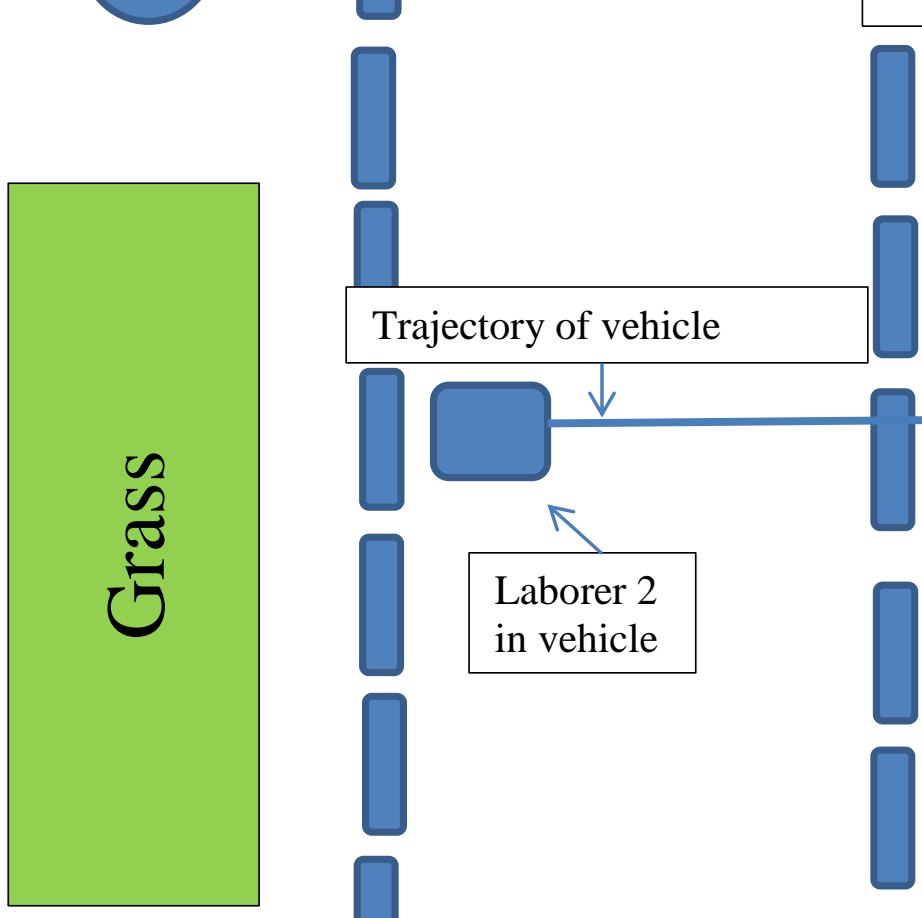

Laborer 2 in vehicle
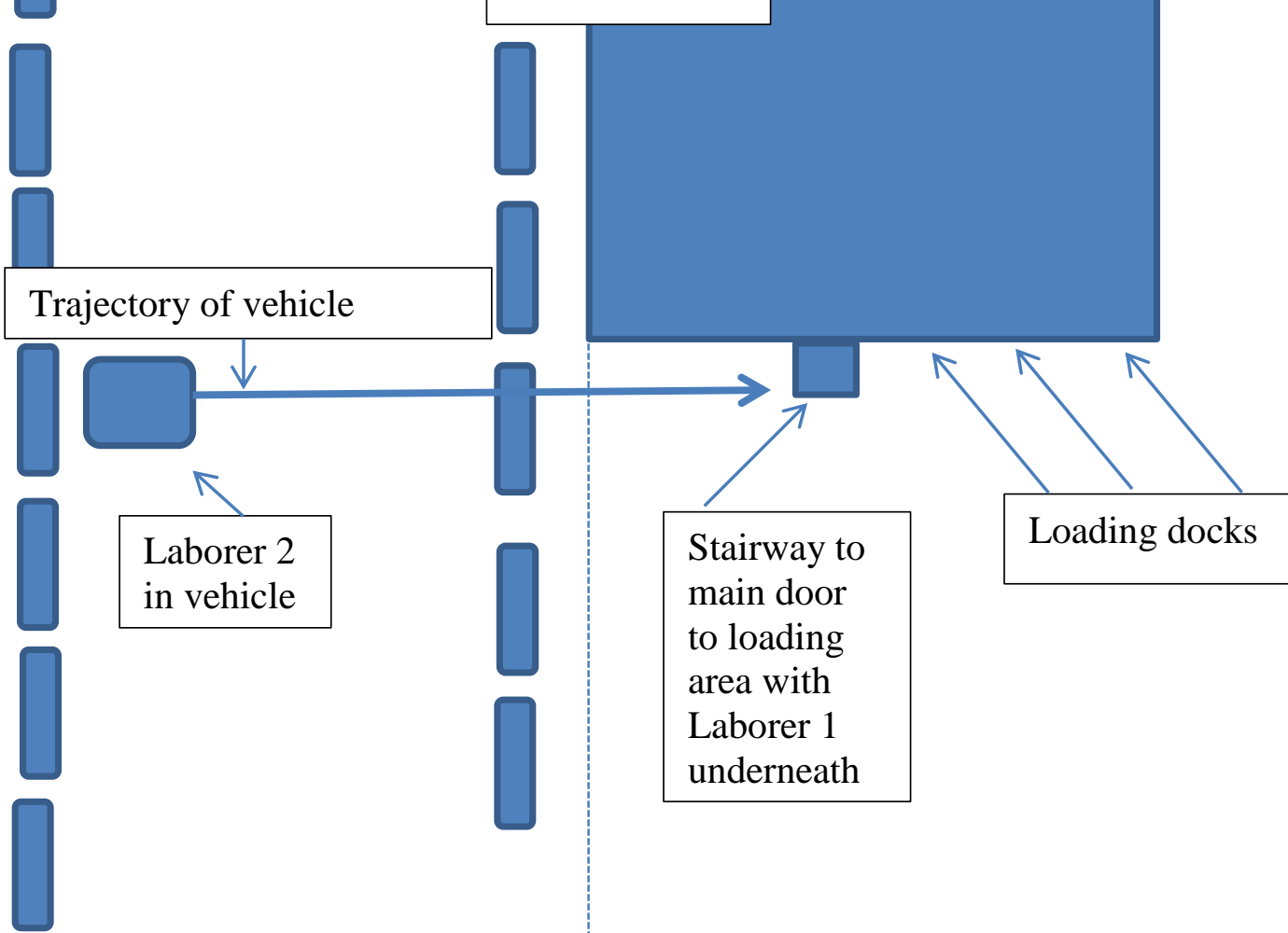

Not to scale

Entrance to employee/visitor parking lot

Entrance to loading dock area 